\title{
Investigation on Potential Starter of Bacillus spp. for Ivorian Cocoa Beans Fermentation Improvement
}

\author{
Alalet Zadi, Gisèle Koua, Ginette Doué*, Sébastien Niamké
}

Laboratoire de Biotechnologies, UFR Biosciences, Université Félix Houphouet-Boigny, 22 BP 582 Abidjan 22, Côte d'Ivoire.

\section{A R T I C L E I N F O}

\section{Research Article}

Received 19 June 2018

Accepted 21 October 2018

Keywords:

Bacillus spp.

Pectinolytic enzymes

Ivorian cocoa

Fermentation

Functional properties

*Corresponding Author:

E-mail: gladysdoue@yahoo.com \begin{abstract}
A B S T R A C T
To investigate some interesting functional properties of Bacillus spp. in cocoa fermentation processing, 702 strains of Bacillus sp. strains were isolated from six main Ivorian cocoa producer regions. Three mains technological and useful properties for good cocoa beans fermentation were monitored. Among the 386 pectinolytic Bacillus spp. strains, $86.79 \%$ of them were confirmed for enzymes production in liquid medium. These 335 pectinolytic Bacillus strains displayed variety of pectinolytic activity with $50.45 \%$ of them producing both pectinase and polygalacturonase (PG) enzymes. Among these 169 strains, $70 \%$ displayed both the ability to acidify the medium and to degrade the citrate. In mimic conditions of $\mathrm{pH}$ and temperature variations as for fermentation heap, 11 strains were able to maintain their activity ranged within $2.12 \pm 0.02$ to $0.41 \pm 0.03$ $\mu \mathrm{mol} / \mathrm{min} / \mathrm{mg}$ of proteins for $\mathrm{PG}$ and $2.36 \pm 0.03$ to $0.25 \pm 0.03 \mu \mathrm{mol} / \mathrm{min} / \mathrm{mg}$ of proteins for pectinase. Two species $\left(\mathrm{T}_{10} \mathrm{~T}_{2}\right.$ and $\left.\mathrm{T}_{6} \mathrm{HS}_{10}\right)$ identified as Bacillus subtilus and Bacillus thuringiensis, were selected as the best based on pectinase production level. They were able to continuously produce both pectinolytic enzymes in different conditions of organic acids and ethanol contents. The highlighted properties in this study and the performance of these two strains may make them best candidate as starters for cocoa fermentation control.
\end{abstract}

DOI: https://doi.org/10.24925/turjaf.v6i12.1758-1767.2078

\section{Introduction}

Cocoa (Theobroma cacao L.) is an important cash crop in developing countries and essential raw material for the manufacture of chocolate (Krähmer et al., 2015). The full development of chocolate flavor precursors requires the fermentation of cocoa beans which is characterized by a succession of indigenous microbial groups including yeasts, LAB, AAB and Bacillus spp. (Schwan and Wheals, 2004; Lima et al., 2011). Microbial fermentation, which takes place in mucilaginous pulp, induces numerous chemical reactions leading to modification of biochemical characteristics of beans (Gill et al., 1985). These biochemical changes contribute to the bitterness and astringency reduction in crude cocoa beans, and also induce the formation of essential precursor compounds of the cocoa flavor (De vuyst et al., 2010). However, cocoa bean fermentation remains an uncontrolled traditional process leading to inconsistent quality of cocoa beans. Indeed, the microorganisms involved in this fermentation are from the hazardous contamination of beans by indigenous strains (Schwan and Wheals, 2004) and are related to local practices.

In order to transform this fermentation into a more efficient process, it is essential to know how each microbial group contributes to the fermentation process and chocolate quality (Saltini et al., 2013). The microbial ecology of cocoa bean fermentation is complex. Indeed, early in this process, yeasts group is favored under anaerobic conditions, high sugar content and low $\mathrm{pH}$. This group produces ethanol with pectinolytic activity. Then, LAB, known to ferment sugar into lactic acid and to degrade citric acid, constitute the second microbial group involved in this process. In the conditions of increased temperature and $\mathrm{pH}, \mathrm{AAB}$ group emerge and oxidize ethanol into acetic acid (Lima et al., 2011). As concerning Bacillus group, the role in cocoa beans fermentation process is less investigated in comparison to other microbial groups and constitutes therefore a controversy subject.

For instance, Bacillus species are thought to be responsible for off flavor of fermented cocoa (Schwan, 2004). They are believed to have no crucial role in cocoa fermentation so they have never been included in any microbial cocktail as starter to control and standardize cocoa fermentation.

However, findings of Ouattara et al. (2008) revealed that Bacillus spp. constitute the microbial group which is present throughout the fermentation process unlike the other microbial groups. Rooijackers et al. (2012) have 
showed that Bacillus species are present during this process at higher level than yeasts, LAB and AAB. In addition, they are, as same as yeast, responsible for production of pectinolytic enzymes (Ouattara et al., 2011). These authors also pointed out that Bacillus spp. are able to produce two types of pectinolytic enzymes (pectin lyase and polygalacturonase) contrary to yeasts that produce only polygalacturonase (PG). More recently, Kouame et al. (2015 a) reported implication of Bacillus in the $\mathrm{pH}$ medium increase by degradation of citrate and acidification of the fermentation heaps. As all these properties such as pectinolytic enzymes production, citrate degradation and acidification capacity are essential for obtaining good quality cocoa beans.

Thus, Bacillussp. strains with such capacities could be more investigated for the selection of potentials starter in order to control cocoa fermentation. The aim of this study was to select potential starters of Bacillus spp. isolated from natural cocoa fermentations based on their technological properties.

\section{Materials and Methods}

\section{Fermentation Conditions}

Cocoa pods were harvested in farms from six cocoa producing regions of Côte d'Ivoire: Cavally $\left(6^{\circ} 25^{\prime} 0\right.$ North $-7^{\circ} 30^{\prime} 0$ West), Gkôklè ( $4^{\circ} 57^{\prime} 04^{\prime \prime}$ north $6^{\circ} 05^{\prime} 19^{\prime \prime}$ West), Gôh (6 $6^{\circ} 15^{\prime} 0$ ', North $5^{\circ} 55^{\prime} 0$ ', West), HautSassandra $\left(7^{\circ} 0^{\prime} 0\right.$ North $-6^{\circ} 34^{\prime} 59$ West), San Pedro ( $4^{\circ}$ 44' 54 North $-6^{\circ} 38^{\prime} 10$ West) and Tonkpi (7 $7^{\circ} 4^{\prime} 45^{\prime}$, North $7^{\circ} 33^{\prime}$ 14', West). Spontaneous cocoa bean fermentation was performed at National Flowers Center of Félix Houphouët-Boigny University, using traditional conditions, with temperature and relative humidity ranging respectively, from 28 to $30^{\circ} \mathrm{C}$, and 60 to $65 \%$ for 6 days. The fermenting mass $(50 \mathrm{~kg})$ set on banana leaves and covered with banana leaves were constituted of mixed genotypes (Forastero, Trinitario and Criollo cultivars). The fermenting heap was mixed and $100 \mathrm{~g}$ beans were collected in sterile Stomacher bag, at the start and each 12 $\mathrm{h}$ of fermentation. A total of 13 samples of each fermenting cocoa mass were collected for microbial analysis.

Temperature and $p H$ Determination of The Fermenting Heap

The temperature and $\mathrm{pH}$ of the fermenting mass were recorded at the start and each $12 \mathrm{~h}$ of fermentation directly at $15 \mathrm{~cm}$ depth of the mass with a portable $\mathrm{pH}$ meter and thermometer (ALLA, France).

\section{Isolation and Enumeration of Bacterial Strains}

Isolation was performed according to the standard method described by Nielsen et al. (2007). An amount of $25 \mathrm{~g}$ of fermenting cocoa beans was homogenized in 225 $\mathrm{mL}$ sterile peptone water ( $\mathrm{pH}$ 7.0). After appropriate dilution of samples in sterile saline solution, $0.1 \mathrm{~mL}$ from each dilution was inoculated onto duplicate plates of nutrient agar (Scharlau Microbiology, Spain) supplemented with $0.1 \%$ nystatin to inhibit the fungal growth. The culture was incubated at $30{ }^{\circ} \mathrm{C}$ for $48 \mathrm{~h}$. Following incubation, the number of colony-forming units (expressed as CFU per gram cocoa pulp bean mass) was recorded. Bacillus spp. isolates, identified using conventional colonial morphology, Gram staining and biochemical reactions according to Bergey's manual of systems bacteriology, were counted and stored at $-80^{\circ} \mathrm{C}$ in nutrient broth supplemented with glycerol $20 \%$ in Eppendorf tubes, for further studies.

\section{Screening of Bacillus spp. Strains for Pectinolytic} Enzymes Production

Pectinolytic enzymes production in solid medium: Bacillus spp. pectinolytic strains were screened using the method described by Soares et al. (1999) and modified by Ouattara et al. (2008). Basal mineral medium was prepared with $0.28 \%\left(\mathrm{NH}_{4}\right)_{2} \mathrm{SO}_{4}, 0.6 \% \quad \mathrm{~K}_{2} \mathrm{HPO}_{4}, 0.01 \%$ $\mathrm{MgSO}_{4}, 0.2 \% \quad \mathrm{KH}_{2} \mathrm{PO}_{4}, 0.02 \%$ yeast extract, $1 \%$ pectin for pectinase or $1 \%$ polygalacturonic acid for polygalacturonase (PG) and $1.7 \%$ agar, $\mathrm{pH}$ 6.8. Four wells of $0.5 \mathrm{~cm}$ in diameter and 2 to $3 \mathrm{~mm}$ in depth were aseptically made in the medium. Then, pure Bacillus culture was suspended in saline tryptone to have an optical density of 1 at $600 \mathrm{~nm}$. $7 \mu \mathrm{L}$ of the suspension were subsequently used to load the wells. All the wells of the same plate were inoculated with a single suspension and incubated at $30{ }^{\circ} \mathrm{C}$ for $48 \mathrm{~h}$. After incubation, the solid culture medium was flooded with a solution of iodine and potassium iodide $(5 \mathrm{~g}$ potassium iodide $+1 \mathrm{~g}$ iodine $+330 \mathrm{~mL}$ distilled water) to reveal the clear zones around the wells indicating pectinolytic activity.

Pectinolytic enzymes production in liquid medium: The ability of selected strains to produce pectinolytic enzymes were confirmed and evaluated in liquid medium.

Culture conditions and enzymes production: Liquid mineral medium was prepared with $0.28 \%\left(\mathrm{NH}_{4}\right)_{2} \mathrm{SO}_{4}$, $0.6 \% \quad \mathrm{~K}_{2} \mathrm{HPO}_{4}, 0.01 \% \quad \mathrm{MgSO}_{4}, 0.2 \% \quad \mathrm{KH}_{2} \mathrm{PO}_{4}, 0.02 \%$ yeast extract, $1 \%$ pectin for pectinase or polygalacturonic acid for polygalacturonase (PG), and $\mathrm{pH}$ 6.8. $1 \mathrm{~mL}$ of bacterial suspension prepared as described above was used to inoculate this medium. Cultures were grown in 50 $\mathrm{mL}$ Erlenmeyer flasks with $10 \mathrm{~mL}$ of medium in a rotary shaker $(150 \mathrm{rpm})$ at $30^{\circ} \mathrm{C}$ for $48 \mathrm{~h}$, in aerobic conditions. Biomass was separated by centrifugation at $15000 \mathrm{rpm}$ for $30 \mathrm{~min}$ at $4^{\circ} \mathrm{C}$. Enzymes activity was measured in the cell-free supernatant.

Protein and enzymes assays: Pectinase and polygalacturonase (PG) activities were determined using pectin and polygalactouronic acid as substrates (MinjaresCassanco et al., 1997). The reaction mixture containing $1 \%$ substrate prepared in phosphate buffer $0.1 \mathrm{M} \mathrm{pH} 6$ and $100 \mu \mathrm{L}$ of cell-free supernatant were incubated at $40^{\circ} \mathrm{C}$ for $30 \mathrm{~min}$. After incubation, $250 \mu \mathrm{L}$ of DNS solution were added to stop the reaction and tubes were kept in boiling water for 5 min. The absorbance was read at $575 \mathrm{~nm}$ after addition of $2 \mathrm{~mL}$ of distilled water using UV-visible spectrophotometer (Milton Roy Spectronic 1001 plus). The amount of released reducing sugar was quantified using galacturonic acid as standard. The enzymes activity was defined as the amount of enzyme required to release one micromole equivalent of galacturonic acid per minute under assay conditions. Proteins content was assessed by Bradford (1976) method using bovine serum albumin as standard. All the experiments were performed in triplicate. 
Screening of Pectinolytic Bacillus spp. Strains for Acidification Capacity

Acidification capacity of pectinolytic Bacillus spp. strains was performed according to the method described by Aydin and Aksoy (2009) with slight modification. The medium made of calcium carbonate agar containing $1 \%$ D-glucose, $0.5 \%$ yeast extract, $0.3 \%$ casein peptone and $1.5 \%$ agar was prepared and supplemented with $0.0016 \%$ bromocresol green, $\mathrm{pH}$ 6.2. A volume of $3 \mathrm{~mL}$ of medium was delivered in a $5 \mathrm{~mL}$ tube and then sterilized for 15 min at $121{ }^{\circ} \mathrm{C}$. Each strain was inoculated with pure $24 \mathrm{~h}$ pre-culture of bacterial strain and incubated at $30{ }^{\circ} \mathrm{C}$ for $48 \mathrm{~h}$. A negative control was prepared in the same conditions but was not inoculated with microbial culture. Acid production was assessed by formation of yellow area in the tube with or not gas production.

\section{Analysis of Pectinolytic Bacillus spp. Strains for Citrate Metabolism}

Pectinolytic Bacillus spp. strains previously identified by their ability to acidify the medium were tested for their ability to degrade citrate by the method described by Beishir (1991). The Simmons citrate medium was inoculated with pure pre-culture and incubated at $30{ }^{\circ} \mathrm{C}$ for $48 \mathrm{~h}$. After incubation, the blue colonies were those able to metabolize citrate.

Effects of Fermentative Conditions ( $\mathrm{pH}$ and Temperature) on Pectinolytic Enzymes Production by Bacillus spp. Strains

The influence of temperature on pectinolytic enzymes produced by Bacillus spp. strains was also evaluated. The variation of enzymes production by temperature was studied on liquid medium described above. Cultures were incubated for $48 \mathrm{~h}$ at different temperatures $\left(30\right.$ to $50^{\circ} \mathrm{C}$ with $5^{\circ} \mathrm{C}$ interval) and then assayed for pectinase and polygalacturonase (PG) activity.

The influence of the $\mathrm{pH}$ on pectinolytic enzymes produced by Bacillus spp. strains was analysed. The modulation of enzymes production by $\mathrm{pH}$ was studied on liquid medium previously described. The basal medium was adjusted at different $\mathrm{pH}(3,4,5,6,7$ and 8). All cultures were incubated during for $48 \mathrm{~h}$ at $30^{\circ} \mathrm{C}$ and then assayed for pectinase and polygalacturonase (PG) activity.

Influence of Organic Acids and Ethanol on Pectinolytic Enzymes Production by Bacillus spp. Strains

Effect of organic acids: The effect of organic acids (citric, lactic and acetic acids) on pectinolytic enzymes production was evaluated as follow: different acid compounds were added to the basal mineral medium at concentrations 0.2 to $1 \%$ for citric acid, 0.1 to $0.6 \%$ for lactic acid and 0.05 to $0.5 \%$ for acetic acid. After incubation, pectinase and polygalacturonase (PG) were assayed as previously described.

Effect of ethanol: To evaluate the effect of ethanol concentration on pectinolytic enzymes production, different concentrations of ethanol $(0,2,4,6$ and 8\%) were added to the basal mineral medium. After incubation, pectinase and polygalacturonase $(\mathrm{PG})$ were assayed as previously described.

\section{Molecular Identification}

16s rRNA gene PCR and sequence analysis: The isolates of Bacillus were grown on Luria Bertani (LB) agar medium during $24 \mathrm{~h}$ of incubation at $30^{\circ} \mathrm{C}$. A loopful of pure culture was suspended in $100 \mu \mathrm{L}$ of sterile distilled water and this sample was used for colony PCR. In this technique, the medium was constituted by microorganisms from one pure colony. After the first stages of denaturation, the released DNA was used as matrix for amplification.

The hypervariable regions $\left(\mathrm{V}_{1}, \mathrm{~V}_{2}\right.$ and $\left.\mathrm{V}_{6}\right)$ of the different Bacillus spp. strains were amplified by using universal primers F27 (5'-AGAGTTTGATCCTGGCTCAG-3') and R520 (5'-ACCGCGGCTGCTGGC-3') (Ouattara et al., 2011) for colony PCR. Each mixture (final volume 50 $\mu \mathrm{L}$ ) contained about $1 \mu \mathrm{L}$ of sample $1.25 \mathrm{U}$ of Taq DNA polymerase (Biolabs, Lyon France), $5 \mu \mathrm{L}$ of $10 \mathrm{x}$ Taq Buffer (10 mMTrisHCl, $\left.50 \mathrm{mMKCl}, 1.5 \mathrm{mM} \mathrm{MgCl}_{2}\right)$, $1 \mu \mathrm{L}$ of $10 \mathrm{mM}$ dNTP, $2 \mu \mathrm{L}$ of each primer $(10 \mathrm{mM})$ (Eurofins, Genomics, Germany) supplemented by sterile water Milli-Q. PCR amplification was carried out in a thermocycler (SensoquestLabcycler). After an initial denaturation at $95^{\circ} \mathrm{C}$ for $4 \mathrm{~min}$, reactions were run for 35 cycles, each cycle comprising denaturation at $95^{\circ} \mathrm{C}$ for 1 min, annealing at $56^{\circ} \mathrm{C}$ for $1 \mathrm{~min}$, extension at $72^{\circ} \mathrm{C}$ for 1 min; and final extension at $72^{\circ} \mathrm{C}$ for $10 \mathrm{~min}$.

Gel electrophoresis: After migration of the products realized at $70 \mathrm{~V}$ for $2 \mathrm{~h}$ in a tank, amplicons were revealed by incubating them on $0.8 \%$ agarose gel electrophoresis in a $1 \mathrm{x}$ phosphate TAE buffer containing ethidium bromide. The molecular weight of the products was estimated in reference to a molecular weight marker (Biolabs, France) of $500 \mathrm{bp}$.

Sequencing and analysis of hypervariable sequence of I6S RNA gene amplified: The PCR products were purified using the nucleospinR Gel and PCR Clean-up kit (MachereyeNagel, Germany) and were then sequenced by MWG Eurofins using the primer F27. The gene sequences obtained were compared to the GenBank database using the BLAST program (BLAST, 2018).

\section{Statistical Analysis}

Data were analyzed using the XLSTAT version 2007 Software and EXCEL. In order to underline the differences between mean values, Duncan's test of the ANOVA was used at $95 \%$ of confidence.

\section{Results and discussion}

Change in Temperature, $p H$ and Dynamics of The Microorganisms During Cocoa Bean Fermentation:

Figure 1 ( $\mathrm{A}$ and $\mathrm{B}$ ) shows the changes of temperature and $\mathrm{pH}$ values for experimental cocoa heap fermentation. The initial temperature (figure 1A) was ranged between $28^{\circ} \mathrm{C}$ (cavally) to $29^{\circ} \mathrm{C}$ (Goh) and then gradually increased to a maximum reached at different fermentation times. Thus, San Pedro and Gboklê first reached (24h) the peak of temperature $\left(40^{\circ} \mathrm{C}\right)$ while Goh and Tonkpi were the last $(72 \mathrm{~h})$ to reach this peak $\left(43\right.$ and $44^{\circ} \mathrm{C}$, respectively). Finally, these temperatures dropped to reach values of $28^{\circ} \mathrm{C}$ for cavally and $32^{\circ} \mathrm{C}$ for Haut Sassandra at the end of fermentation. Analysis of heap spontaneous fermentation conditions indicates that the $\mathrm{pH}$ (figure 1B) of fermentation heap ranged from 3.4 (Tonkpi) to 4.0 (Gôh) at the beginning and increased to 
reach maximum $\mathrm{pH}$ values (7.7 to 8.1$)$ at the end of the fermentation process. The same profile of temperature and $\mathrm{pH}$ variation has been recorded in cocoa fermenting mass in other studies (Papalexandratou and De Vuyst, 2011; Guehi et al., 2010) indicating that the increase of both parameters constitutes an inherent property of cocoa fermentation worldwide. Moreover, $\mathrm{pH}$ continuously increasing during the fermentation became alkaline at the end of the process. Guehi et al. 2010 and Ouattara et al. 2014 also reported an alkaline $\mathrm{pH}$ at the end of spontaneous cocoa fermentation in Côte d'Ivoire.

The dynamic of Bacillus spp population obtained from numeration during fermentation of cocoa from six major producing regions of Côte d'Ivoire is depicted in Figure 2. In general, these strains exhibited similar growth profile. Indeed, they were present at the beginning of the fermentation at varying loads between 3.98 and $5.54 \mathrm{log}$ $\mathrm{CFU} / \mathrm{g}$ of beans for San Pedro and Cavally regions, respectively. Then, this microbial population gradually increased throughout the fermentation to a maximum load between 8.13 to $8.66 \mathrm{log}$ CFU/g of beans after $144 \mathrm{~h}$ of fermentation time for Gôh and San Pedro regions, respectively. The presence of these microorganisms at the beginning on these fermentation heaps could be due to an accidental inoculation by microorganisms from the pod surface, knives, labors hands, fermentary (Grimaldi, 1978, Thompson, 2001).

\section{Highlighting Bacillus Strains Pectinolytic Activity}

So, it is in this environment that seven hundred two (702) strains of Bacillus were isolated from cocoa fermentation of the six studied regions. These strains were screened for their ability to produce pectinolytic enzymes. This screening was first carried out in a solid medium because of the large number of isolated strains (Table 1). The results showed that more than half $(54.98 \%)$ of isolates corresponding to 386 strains exhibited pectinolytic activity in plate assay (solid medium) as revealed by the clear halo. Among these 386 Bacillus spp. strains exhibiting pectinolytic activity in solid medium only $86.79 \%$ (335 strains) of them confirm this activity in liquid medium (Table 2). In addition, $50.54 \%$ of strains with pectinolytic activity in liquid medium (169 strains) produced both pectinase and PG. These findings are consistent with previous studies that have shown that strains of Bacillus spp. isolated from Ivoirian cocoa fermentation mainly produced both types of pectinolytic enzymes, polygalacturonase (PG) and pectinase (Ouattara et al., 2008), unlike yeasts that produce only polygalacturonase (PG) enzyme (Schwan et al., 1997).

The results of this study clearly highlight the role of Bacillus strains in the degradation of pectin as yeasts (Schwan et al., 1997). Furthermore, these isolates of Bacillus spp. strains may play a predominant and active part in this process as they are able to display both types of pectinolytic activity (pectinase and PG) compared to that reported $(\mathrm{PG})$ for the yeasts by Samagaci et al. (2014).Therefore, these 169 strains capable of producing both types of pectinolytic enzymes are potentially interesting as they display an important and desirable property for adequate fermentation (Aydin and Aksoy, 2009; Afokwa et al., 2013).
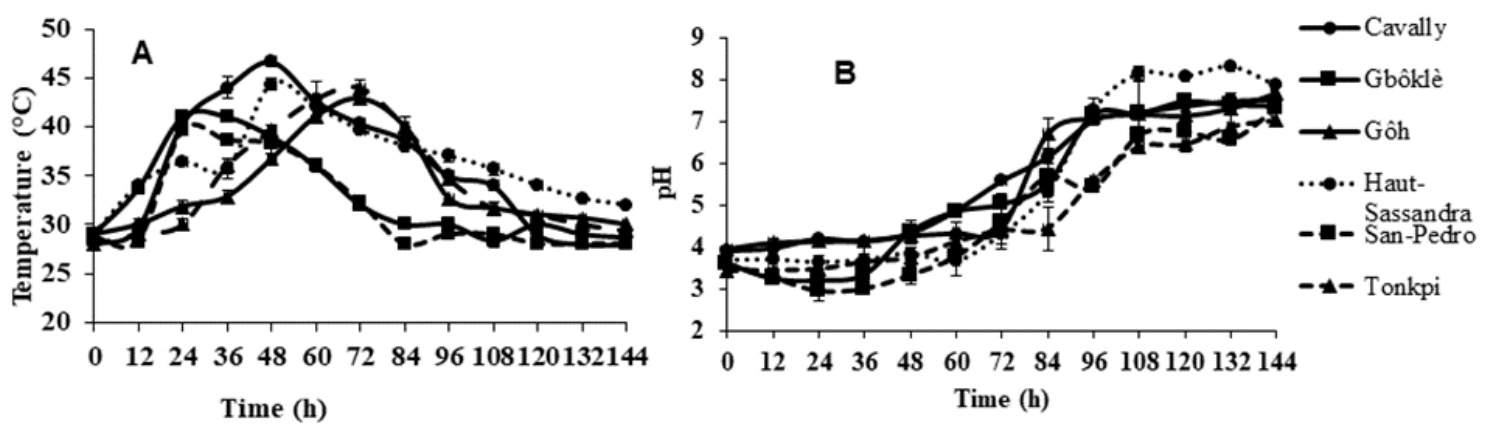

Figure 1 Evolution of temperature $(\mathrm{A})$ and $\mathrm{pH}(\mathrm{B})$ during cocoa beans fermentation of the six studied regions Error bar indicate and standard deviations between three replicates

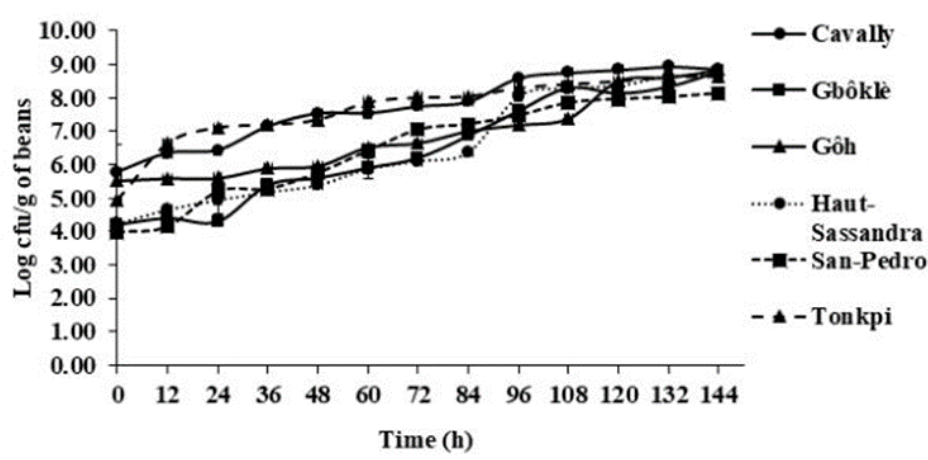

Figure 2 Bacillus strains growth dynamic during cocoa heap fermentation of the six studied regions Bacillus population is presented as means and standard deviation 
Table 1 Distribution of pectinolytic Bacillus isolates and nature of pectinolytic enzymes produced in solid medium

\begin{tabular}{l|ccccc}
\hline \multirow{2}{*}{ Régions } & \multirow{2}{*}{ Total Isolates } & \multirow{2}{*}{ NIPEA } & \multicolumn{2}{c}{ Number of Isolates producing pectinolytic Enzyme In solid medium } \\
\cline { 4 - 6 } & & & Only Pectinase & Only PG & Pectinase and PG \\
\hline Cavally & $128(18.23 \%)$ & $35(09.06 \%)$ & $05(07.46 \%)$ & $08(05.88 \%)$ & $22(12.02 \%)$ \\
Gbôklé & $112(15.95 \%)$ & $45(11.66 \%)$ & $08(11.94 \%)$ & $13(09.56 \%)$ & $24(13.11 \%)$ \\
Gôh & $118(16.81 \%)$ & $86(22.28 \%)$ & $13(19.40 \%)$ & $56(41.18 \%)$ & $17(09.29 \%)$ \\
HautSassandra & $118(16.81 \%)$ & $78(20.21 \%)$ & $23(34.33 \%)$ & $18(13.23 \%)$ & $37(20.22 \%)$ \\
San Pédro & $95(13.63 \%)$ & $55(14.25 \%)$ & $13(19.40 \%)$ & $09(06.62 \%)$ & $33(18.03 \%)$ \\
Tonkpi & $131(18.66 \%)$ & $87(22.54 \%)$ & $05(07.46 \%)$ & $32(23.53 \%)$ & $50(27.32 \%)$ \\
Total & $702(100 \%)$ & $386(54.98 \%)$ & $67(17.36 \%)$ & $136(35.23 \%)$ & $183(47.41 \%)$ \\
\hline
\end{tabular}

NIPEA: Number of Isolates with Pectinolytic Enzymes Activity; PG: Polygalacturonase

Table 2 Distribution of pectinolytic Bacillus isolates and nature of pectinolytic enzymes produced in liquid medium

\begin{tabular}{l|ccccc}
\hline \multirow{2}{*}{ Regions } & \multirow{2}{*}{ TPS Isolates in Solid medium } & \multicolumn{4}{c}{ Number of Isolates producing pectinolytic Enzyme In liquid medium } \\
\cline { 2 - 6 } & & TotalIsolates & Only Pectinase & Only PG & Pectinase and PG \\
\hline Cavally & $35(09.07 \%)$ & $31(09.25 \%)$ & $04(08.69 \%)$ & $07(05.83 \%)$ & $20(11.83 \%)$ \\
Gbôklé & $45(11.66 \%)$ & $39(11.64 \%)$ & $05(10.87 \%)$ & $12(10 \%)$ & $22(13.02 \%)$ \\
Gôh & $86(22.28 \%)$ & $71(21.19 \%)$ & $10(21.74 \%)$ & $49(40.83 \%)$ & $12(07.10 \%)$ \\
HautSassandra & $78(20.21 \%)$ & $64(19.10 \%)$ & $17(36.95 \%)$ & $15(12.5 \%)$ & $32(18.93 \%)$ \\
San Pédro & $55(14.25 \%)$ & $47(14.03 \%)$ & $08(17.39 \%)$ & $06(05 \%)$ & $33(19.52 \%)$ \\
Tonkpi & $87(22.53 \%)$ & $83(24.79 \%)$ & $02(04.35 \%)$ & $31(25.83 \%)$ & $50(29.58 \%)$ \\
Total & $386(100 \%)$ & $335(86.79 \%)$ & $46(13.73 \%)$ & $120(35.82 \%)$ & $169(50.45 \%)$ \\
\hline
\end{tabular}

TPS means Total Pectinolytic Strains; PG means Polygalacturonase

Table 3 Distribution of Bacillus sp. strains isolates according to their technological properties

\begin{tabular}{l|ccc}
\hline \multirow{2}{*}{ Regions } & \multicolumn{3}{c}{ Number of } \\
\cline { 2 - 4 } & PSI & PSAC & PASCDC \\
\hline Gbôklé & $22(12.02 \%)$ & $20(18.18 \%)$ & $06(07.79 \%)$ \\
HautSassandra & $32(18.93 \%)$ & $26(23.64 \%)$ & $22(28.57 \%)$ \\
San Pédro & $33(19.53 \%)$ & $30(27.27 \%)$ & $11(14.29 \%)$ \\
Tonkpi & $50(29.59 \%)$ & $16(14.55 \%)$ & $07(09.09 \%)$ \\
Cavally & $20(11.83 \%)$ & $12(10.91 \%)$ & $03(03.90 \%)$ \\
Gôh & $12(07.10 \%)$ & $06(05.45 \%)$ & $77(70 \%)$ \\
Total & $169(100 \%)$ & $110(65.09 \%)$ & $(76)$ \\
\hline
\end{tabular}

PSI: Pectinolytic Strains Isolates; PSAC: Pectinolytic Strains with Acidifying Capacity; PASCD: Pectinolytic and Acidifying Strains with Citrate Degradation Capacity

Acidification Capacity and Citrate Degradation of Bacillus spp. Pectinolytic Strains

Acidifying capacity and citrate metabolism stand one of the most relevant and useful desired properties in cocoa fermentation (Kouame et al., 2015a; Kouame et al., 2015b). Biochemical characterization of pectinolytic Bacillus spp. strains previously isolated showed that among the 169 pectinolytic isolates, 70\% displayed both, ability to acidify the medium and to degrade the citrate (Table 3). These results showed that the isolated strains have an unequal regions distribution with San Pedro and Haut Sassandra recording the highest number of isolates $36.36 \%$ and $28.57 \%$, respectively (Table 3). This variability is not surprising since the local geographic area is an important factor influencing the composition of the microflora involved in cocoa fermentation as reported by Schwan and Wheals (2004).

Indeed, these pectinolytic Bacillus spp. strains with acidifying and citrate degradation capacities showed halo diameter between 1 and $3.5 \mathrm{~cm}$ for pectinase and between 1 and $3.4 \mathrm{~cm}$ for polygalacturonase (PG) in solid medium. These results were confirmed in liquid medium where these Bacillus spp. strains were able to maintain their pectinolytic enzymes activities. The Table 4 showed the different level of pectinolytic enzymes production by these strains. It is observed that all the studied strains produced these both types of pectinolytic enzymes such as pectinase and polygalacturonase (PG) with different activity level ranged within $0.11 \pm 0-2.62 \pm 0.09$ $\mu \mathrm{mol} / \mathrm{min} / \mathrm{mg}$ of proteins and $0.12 \pm 0.02-1.84 \pm 0.02$ $\mu \mathrm{mol} / \mathrm{min} / \mathrm{mg}$ of proteins, respectively. This could allow to degrade faster and more effectively the pulp-rich pectin and thus contribute to the aeration of the fermentation heap. In addition, these 77 acidifying Bacillus spp. pectinolytic strains may be useful for various enzymatic activities as developing the characteristic aroma and flavour of cocoa and chocolate (Schwan and Wheals, 2004; Thompson et al., 2007), the same way as the AAB. Similarly, by their ability to degrade citrate, these Bacillus spp. pectinolytic strains may also contribute to modulate the $\mathrm{pH}$ of the medium (Schwan and Wheals, 2004), necessary for the emergence and growth of beneficial microorganism as yeasts and LAB. In this point of view, absence of Bacillus spp. during the cocoa beans fermentation may be a limiting factor for this process. 
Influence of Temperature and $\mathrm{pH}$ on Pectinolytic Enzymes Production

The ability of the 77 selected strains to maintain their enzymes production capacity at temperatures up to $55^{\circ} \mathrm{C}$ is depicted in Table 5. Only 14 of them maintained their enzymes production under $50^{\circ} \mathrm{C}$.

Cocoa fermentation is generally characterized by high temperature up to $47-50^{\circ} \mathrm{C}$ occurring at $48-72 \mathrm{~h}$ of fermentation (Papalexandratouet al., 2011; Koffi et al., 2017). As Bacillus spp. is known to be permanent throughout cocoa beans fermentation (Ardhana and Fleet, 2003), these 14 heat-resistant strains may therefore maintain their pectinolytic activity during these periods of high variation of temperature.

In addition, the rate of enzymes produced by these heat-resistant strains in liquid medium varied depending of strains. These rates ranged between $0.20 \pm 0.01$ to $2.52 \pm 0.09 \mu \mathrm{mol} / \mathrm{min} / \mathrm{mg}$ of proteins for pectinase and between $0.40 \pm 0.02$ to $1.32 \pm 0.04 \mu \mathrm{mol} / \mathrm{min} / \mathrm{mg}$ of proteins for polygalacturonase (PG) production (Table 5). In view to these results we mayassess that these heat-resistant strains could beable to maintain a satisfactory level of enzymes production in these conditions of temperature variation. On the other hand, the effect of $\mathrm{pH}$ variations on these 14 heat-resistant strains, showed that only 11 of them were able to maintain continuously their pectinolytic enzymes production for $\mathrm{pH}$ varying from 3.5 to 8 .

Regarding the rate of different pectinolytic enzymes produced by these 11 pectinolytic Bacillus spp. strains, the enzymes production ranged between $2.36 \pm 0.03$ to $0.25 \pm 0.03 \mu \mathrm{mol} / \mathrm{min} / \mathrm{mg}$ of proteins for pectinase production and $2.12 \pm 0.02$ to $0.41 \pm 0.03 \mu \mathrm{mol} / \mathrm{min} / \mathrm{mg}$ of proteins for polygalacturonase (PG) (Table 6). This finding pointed out the fact that these Bacillus spp. strains do not have the same capacity of adaptation to temperature and $\mathrm{pH}$ fluctuations of the fermentative heaps.

Table 4 Level of pectinolytic enzymes (pectinase and PG) production in both solid and liquid medium

\begin{tabular}{|c|c|c|c|c|}
\hline \multirow{2}{*}{\multicolumn{2}{|c|}{ Total of Bacillus strain }} & PSI & PSAC & PASCDC \\
\hline & & 169 & 110 & 77 \\
\hline \multirow{2}{*}{ Halo diameter $(\mathrm{cm})$} & $\mathrm{PC}$ & $1-3.8$ & $1-3.5$ & $1-3.5$ \\
\hline & PG & $1-3.6$ & $1-3.6$ & $1-3.4$ \\
\hline \multirow{2}{*}{ Enzyme Production ( $\mu \mathrm{mol} / \mathrm{min} / \mathrm{mg}$ Prot $)$} & $\mathrm{PC}$ & $0.11 \pm 0.01-2.93 \pm 0.09$ & $0.11 \pm 0.01-2.62 \pm 0.09$ & $0.11 \pm 0.00-2.62 \pm 0.09$ \\
\hline & PG & $0.1 \pm 0.01-4.68 \pm 0.08$ & $0.12 \pm 0.00-4.68 \pm 0.08$ & $0.12 \pm 0.02-1.84 \pm 0.02$ \\
\hline
\end{tabular}

PG: Polygalacturonase; PC: Pectinase; PSI: Pectinolytic Strains Isolates; PSAC: Pectinolytic Strains with Acidifying Capacity; PASCD: Pectinolytic and Acidifying Strains with Citrate Degradation Capacity

Table 5 Effect of temperature on pectinolytic enzymes production from pectinolytic acidifying strains with citrate degradation

\begin{tabular}{ll|cccccc}
\hline \multirow{2}{*}{ N.S.P.E.P. } & & $30{ }^{\circ} \mathrm{C}$ & $35{ }^{\circ} \mathrm{C}$ & $40{ }^{\circ} \mathrm{C}$ & $45{ }^{\circ} \mathrm{C}$ & $50{ }^{\circ} \mathrm{C}$ & $55{ }^{\circ} \mathrm{C}$ \\
\cline { 3 - 8 } & & 77 & 73 & 45 & 25 & 14 & 01 \\
\hline \multirow{2}{*}{ Halo dia-meter $(\mathrm{cm})$} & $\mathrm{PC}$ & $1-3.5$ & $1-3.5$ & $1.3-3.5$ & $1.3-3.5$ & $1.5-3.1$ & $2.4 \pm 0.01$ \\
& $\mathrm{PG}$ & $1-3.6$ & $1-3.6$ & $1.2-3.2$ & $1.2-3.2$ & $1.2-3.2$ & $1.9 \pm 0.00$ \\
\hline Enzymes production & $\mathrm{PC}$ & $0.1-2.62$ & $0.11-2.62$ & $0.15-2.62$ & $0.26-2.62$ & $0.20-2.52$ & $0.2 \pm 0.01$ \\
$(\mu \mathrm{mol} / \mathrm{min} / \mathrm{mg}$ protein) & $\mathrm{PG}$ & $0.1-4.68$ & $0.13-1.84$ & $0.26-1.84$ & $0.28-1.84$ & $0.40-1.32$ & $1.2 \pm 0.00$ \\
\hline
\end{tabular}

PG means polygalacturonase; PC: Pectinase; N.S.P.E.P. means Number of Strain with Pectinolytic Enzyme Production

Table 6 Ranking of pectinolytic Bacillus strains according to pectinase production capacity

\begin{tabular}{l|cc}
\hline \multirow{2}{*}{ Isolates } & \multicolumn{2}{|c}{ Enzymes Production $(\mu \mathrm{mol} / \mathrm{min} / \mathrm{mg}$ de proteins $)$} \\
\cline { 2 - 3 } & Pectinase & PG \\
\hline $\mathrm{T}_{10} \mathrm{~T}_{2}$ & $2.36 \pm 0.03^{\mathrm{a}} \pm 0.02^{\mathrm{f}}$ \\
$\mathrm{T}_{6} \mathrm{HS}_{10}$ & $1.78 \pm 0.04^{\mathrm{b}}$ & $2.12 \pm 0.02^{\mathrm{a}}$ \\
$\mathrm{T}_{4} \mathrm{SP}_{4}$ & $0.86 \pm 0.04^{\mathrm{c}}$ & $0.93 \pm 0.02^{\mathrm{e}}$ \\
$\mathrm{T}_{12} \mathrm{SP}_{17}$ & $0.80 \pm 0.04^{\mathrm{d}}$ & $0.94 \pm 0.02^{\mathrm{e}}$ \\
$\mathrm{T}_{4} \mathrm{~T}_{3}$ & $0.78 \pm 0.02^{\mathrm{d}}$ & $0.41 \pm 0.03^{\mathrm{h}}$ \\
$\mathrm{T}_{4} \mathrm{HS}$ & $0.76 \pm 0.04^{\mathrm{d}}$ & $1.53 \pm 0.04^{\mathrm{b}}$ \\
$\mathrm{T}_{5} \mathrm{HS}_{2}$ & $0.59 \pm 0.04^{\mathrm{e}}$ & $1.32 \pm 0.04^{\mathrm{c}}$ \\
$\mathrm{T}_{1} \mathrm{HS}_{1}$ & $0.47 \pm 0.03^{\mathrm{f}}$ & $0.83 \pm 0.03^{\mathrm{f}}$ \\
$\mathrm{T}_{7} \mathrm{HS}_{3}$ & $0.41 \pm 0.03^{\mathrm{g}}$ & $1.10 \pm 0.04^{\mathrm{d}}$ \\
$\mathrm{T}_{12} \mathrm{SP}_{4}$ & $0.58 \pm 0.03^{\mathrm{e}}$ & $0.98 \pm 0.04^{\mathrm{e}}$ \\
$\mathrm{T}_{11} \mathrm{SP}_{4}$ & $0.25 \pm 0.03^{\mathrm{h}}$ & $0.62 \pm 0.03^{\mathrm{g}}$ \\
\hline
\end{tabular}

Data are represented as means \pm SEM $(n=3)$. Mean with different letters in the same row are statistically different $(\mathrm{P}<0.05)$ according to Duncan's test. Legend: In bold, two Bacillussp strains with highest values of pectinase and polygalacturonase activities. 


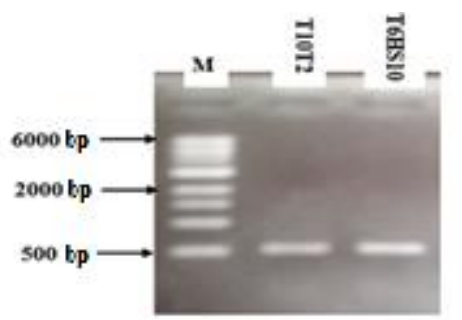

Figure 3 Electrophoretic profile of the PCR products of the hypervariable region of the $16 \mathrm{~S}$ rRNA gene from the two potential starters Bacillus (M: Molecular weight marker, ladders)

Thus, these strains were classified based on their ability to degrade pectin which is, contrary to the polygalacturonic acid, one of the major constituent of cocoa beans. At the end of this ranking, only two of them namely $\mathrm{T}_{10} \mathrm{~T}_{2}$ and $\mathrm{T}_{6} \mathrm{HS}_{10}$ were of interest for the fermentation process as potential starter.

\section{S rRNA Gene PCR and Identification of Isolates}

Amplification of hypervariable regions (V1, V2 and V6) of the $16 \mathrm{~S}$ gene of two potential starters Bacillus by colony PCR yielded a DNA fragment of about $500 \mathrm{bp}$ (Figure 3). The sequencing analysis of amplified hypervariable regions showed that $\mathrm{T}_{6} \mathrm{HS}_{10}$ had $491 \mathrm{bp}$ and $\mathrm{T}_{10} \mathrm{~T}_{2}$ had $477 \mathrm{bp}$, respectively. Analysis of these DNA fragments in the NCBI data bank has enabled us to identify these two Bacillus isolates as belonging to Bacillus thuringiensis for $\mathrm{T}_{6} \mathrm{HS}_{10}$ and to Bacillus subtilis for $\mathrm{T}_{10} \mathrm{~T}_{2}$ with $99 \%$ of similarity.

These identified species are widely used in food industry for its ability to produce extracellular enzymes such as amylases, chitinases and pullunases (Thamthiankul et al., 2001) and non-food agricultural biopesticide (Sharma et al., 2002).
Influence of Additional Stress on Pectinolytic Enzymes Production by Bacillus spp.

Temperature and $\mathrm{pH}$ variations are not the sole fermentative conditions that strongly influence the strains performance. Thus, the two Bacillus sp. strains previously selected and identified as Bacillus thuringiensis and Bacillus subtilis were tested to assess the influence of key parameters such as acids (acetic, lactic and citric) and alcohol (ethanol). The ability to maintain their pectinolytic enzymes production was also evaluated.

\section{Effect of Acids on Pectinolytic Enzymes Production}

In acid conditions induced by lactic, acetic and citric acids, the two selected strains proved to be able to maintain their potential of pectinolytic enzymes (pectinase and PG) production despite the observed decline (Figures 4, 5 and 6).

Overall, increasing concentration of lactic acid led to the decrease in the production of these pectinolytic enzymes after reaching a maximum (Figures $4 \mathrm{~A}$ and $4 \mathrm{~B}$ ). Indeed, pectinase production occurred until $0.4 \%$ of lactic acid with a maximum of $2.99 \mu \mathrm{mol} / \mathrm{min} / \mathrm{mg}$ of Proteins for $\mathrm{T}_{10} \mathrm{~T}_{2}$ while for $\mathrm{T}_{6} \mathrm{HS}_{10}$, only $0.2 \%$ of this acid led to the maximum of $2.51 \mu \mathrm{mol} / \mathrm{min} / \mathrm{mg}$ of Proteins (Figure 4A). Concerning PG, influence of lactic acid the strain $\mathrm{T}_{10} \mathrm{~T}_{2}$ reached a maximum of $1.12 \mu \mathrm{mol} / \mathrm{min} / \mathrm{mg}$ of Proteins at $0.1 \%$ of lactic acid while the strain $\mathrm{T}_{6} \mathrm{HS}_{10}$ recorded the maximum of $2.29 \mu \mathrm{mol} / \mathrm{min} / \mathrm{mg}$ of Proteins at $0.2 \%$ of the same acid (Figure 4B). Subsequently, the production of these two pectinolytic enzymes gradually decreased to maintain at $78.39 \%$ and $98.82 \%$ of the initial level for pectinase and $30.12 \%$ and $68.40 \%$ (PG) of the initial level for $\mathrm{T}_{10} \mathrm{~T}_{2}$ and $\mathrm{T}_{6} \mathrm{HS}_{10}$, respectively (Figures $4 \mathrm{~A}$ and $4 \mathrm{~B})$.
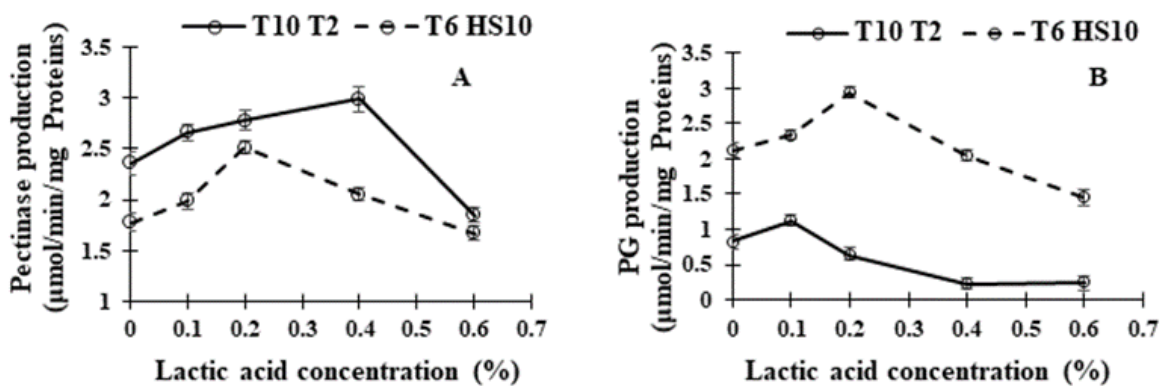

Figure 4 Effect of lactic acid on pectinase (A) and polygalacturonase (B) production by the two selected pectinolytic Bacillus strains
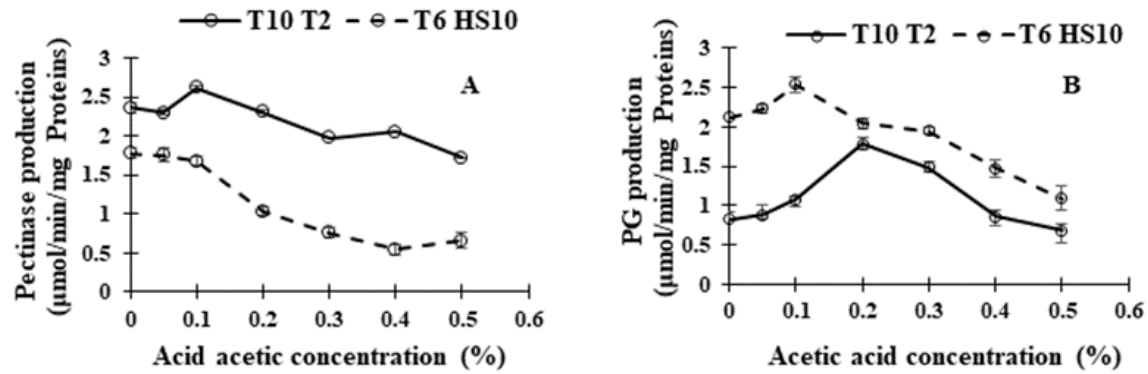

Figure 5 Effect of acetic acid on pectinase (A) and polygalacturonase (B) production by the two selected pectinolytic Bacillus strains 

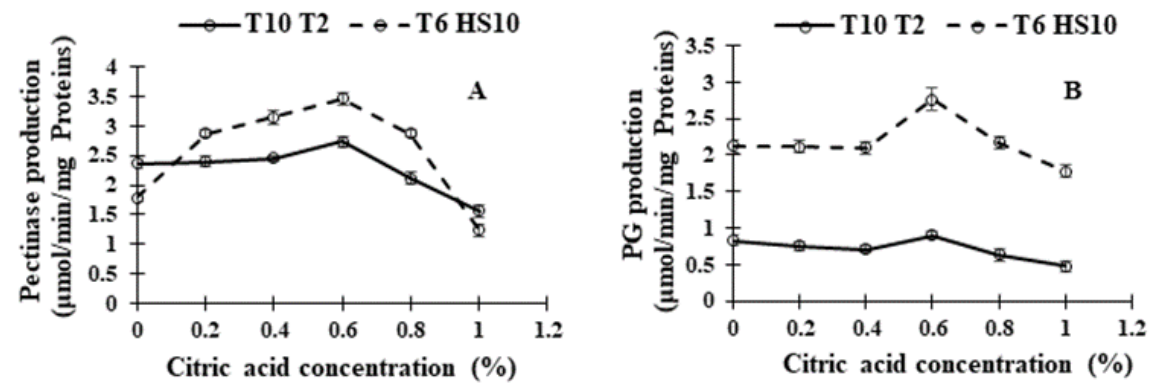

Figure 6 Effect of citric acid on pectinase (A) and polygalacturonase (B) production by the two selected pectinolytic Bacillus strains
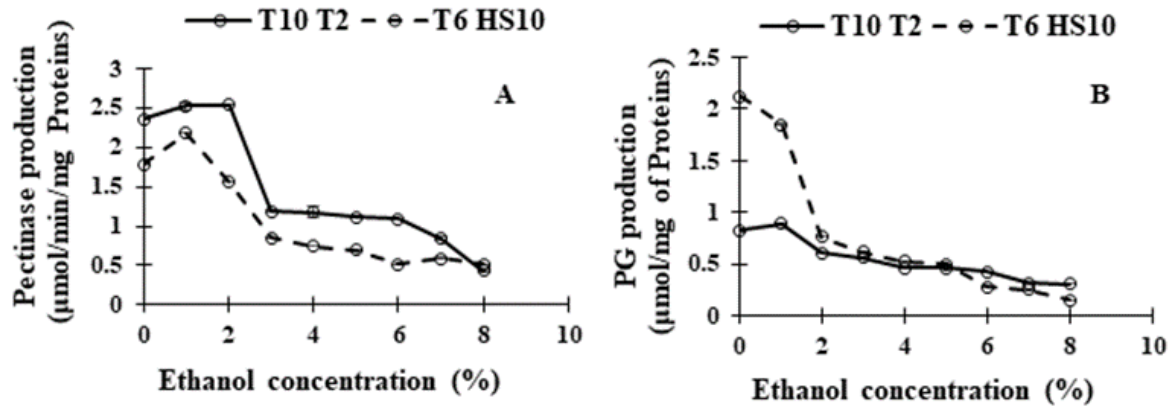

Figure 7 Effect of ethanol on pectinase (A) and polygalacturonase (B) production by the two selected pectinolytic Bacillus strains

As for acetic acid, the influence was stronger than that observed with lactic acid (Figures 5A and 5B). Indeed, there was an increase in pectinase production up to only $0.1 \%$ of acetic acid where the maxima of 1.26 $\mu \mathrm{mol} / \mathrm{min} / \mathrm{mg}$ of Proteins and $1.16 \% \mu \mathrm{mol} / \mathrm{min} / \mathrm{mg}$ of Proteins were recorded for $\mathrm{T}_{10} \mathrm{~T}_{2}$ and $\mathrm{T}_{6} \mathrm{HS}_{10}$, respectively (Figure 5A). For PG, the production occurred up to $0.1 \%$ and $0.2 \%$ of acetic acid with a maximum of 1.78 $\mu \mathrm{mol} / \mathrm{min} / \mathrm{mg}$ of Proteins and $2.54 \mu \mathrm{mol} / \mathrm{min} / \mathrm{mg}$ of Proteins for $\mathrm{T}_{10} \mathrm{~T}_{2}$ and $\mathrm{T}_{6} \mathrm{HS}_{10}$, respectively (Figure 5B). Influence of citric acid on enzyme production by the two Bacillus strains was less sharp than the other studied acids (Figures 6A and 6B). Indeed, the production of pectinase by $\mathrm{T}_{6} \mathrm{HS}_{10}$ increased strongly up to a maximum of 2.45 $\mu \mathrm{mol} / \mathrm{min} / \mathrm{mg}$ of Proteins at $0.6 \%$ of citric acid, then dropped to $69.66 \%$ of the initial level at $1 \%$ of citric acid. As for $\mathrm{T}_{10} \mathrm{~T}_{2}$, a small increase of this pectinolytic enzyme was recorded up to $2.73 \mu \mathrm{mol} / \mathrm{min} / \mathrm{mg}$ of Proteins at $0.6 \%$ of this citric acid followed by a decline to reach $63.56 \%$ of the initial production level (Figure 6A). In contrast to pectinase, citric acid had much less influence on PG production. In fact, a slight decrease in the production of this enzyme up to $56.62 \%$ and $83.96 \%$ of the initial level for $\mathrm{T}_{10} \mathrm{~T}_{2}$ and $\mathrm{T}_{6} \mathrm{HS}_{10}$ was observed, respectively (Figure $6 \mathrm{~B})$.

With the ability to maintain their enzymatic performance despite the $\mathrm{pH}$ fluctuations throughout cocoa beans fermentation, the two strains $\mathrm{T}_{10} \mathrm{~T}_{2}$ and $\mathrm{T}_{6} \mathrm{HS}_{10}$ should be particularly interesting as starters.

Effect of Ethanol on Pectinolytic Enzymes Production

The influence of ethanol concentration on polyglacturonase (PG) and pectinase production is shown in Figures 7 (A and $\mathrm{B}$ ). The results suggested that, the two studied Bacillus strains maintained a good level of pectinolytic enzymes production between 0 and $8 \%$ of ethanol concentration. For both studied Bacillus strains, increasing concentrations ( 0 to $3 \%$ ) of ethanol influence the production of both types of pectinolytic enzyme. Indeed, after a maximum of pectinase production at $1 \%$ $\left(\mathrm{T}_{6} \mathrm{HS}_{10}\right)$ and $2 \%\left(\mathrm{~T}_{10} \mathrm{~T}_{2}\right)$, a sharp drop of this production was observed to $58.20 \%\left(\mathrm{~T}_{10} \mathrm{~T}_{2}\right)$ and $47.52 \%\left(\mathrm{~T}_{6} \mathrm{HS}_{10}\right)$ of initial level (Figure 7A).. Between 3 and $8 \%$ of ethanol, Bacillus strains recorded a substantially stable production about $21.19 \%\left(\mathrm{~T}_{10} \mathrm{~T}_{2}\right)$ and $29.21 \%\left(\mathrm{~T}_{6} \mathrm{HS}_{10}\right)$ of the initial level for the pectinase and $44.58 \%\left(\mathrm{~T}_{10} \mathrm{~T}_{2}\right)$ and $12 \%$ of the initial level for PG.

These results are interesting because ethanol is a major metabolite of cocoa pulp fermentation (Roelofsen, 1958) and the maximum rate of ethanol produced by yeasts is around $8 \%$ during this process (Lefeber et al., 2012; Ho et al., 2014). So, these two isolates could be used in combination with high ethanol producing yeast isolates to improve the final fermenting cocoa quality.

\section{Conclusion}

This study revealed that Bacillus isolated from Ivorian cocoa displayed interesting technological properties such as pectinolytic enzymes production, acidification capacity and citrate degradation. Only two of them $\left(\mathrm{T}_{10} \mathrm{~T}_{2}\right.$ and $\mathrm{T}_{6} \mathrm{HS}_{10}$ ), belonging to Bacillus subtilis and Bacillus thuringiensis were able to maintain these useful properties under the different stress that occur during coca bean fermentation. That make them potential candidate as starter for cocoa fermentation control. 


\section{Acknowledgements}

This work was supported by a Ph.D grant to the first author. The authors are grateful to the National Flowers Center of Felix Houphouët-Boigny University for their availability and support during the fermentations.

\section{References}

Afoakwa EO, Kongor JE, Takrama JF. Budu AS. 2013. Changes in acidification, sugars and mineral composition of cocoa pulp during fermentation of pulp pre-conditioned cocoa (Theobroma cacao) beans. Int. Food Res. J., 20(3): 2151222.

Ardhana M, Fleet G. 2003. The microbial ecology of cocoa bean fermentations inIndonesia. Int. J. Food. Microbiol, 86:8799. DOI: $10.1016 / \mathrm{S} 0168-1605(03) 00081-3$

Aydin YA, Aksoy DN. 2009. Isolation of cellulose producing bacteria from wastes of vinegar fermentation. Proceedings of the World Congress on Engineering and Computer Science, 8: 978-988.

Beishir L. 1991. Microbiology in practice: A Self-instructional laboratory course, Fifth Edition (Harper Collins: New York), 123-345.

BLAST. 2018. Basic Local Alignment Search Tool program (http://www.ncbi.nlm.nih.gov/BLAST/)

Bradford MM. 1976. A rapid and sensitive method for the quantification of microgram quantities of protein utilizing the principle of protein-dye binding. Anal. Biochem, 72:248 -254. DOI: 10.1016/0003-2697(76)90527-3

De Vuyst L, LefeberT, Papalexandratou Z, Camu N. 2010. The functional role of lactic acid bacteria in cocoa bean fermentation. In Mozzi F, Raya RR, Vignolo GM. (Eds) Biotechnology of Lactic Acid Bacteria - Novel Application, Wiley-B1., pp 301-326.

Gill MS, Mc Leod AJ, Moreau M. 1985. Aroma components of cocoa beans. In: Adda J (ed) Proceedings of the 4th Weurman flavor research symposuim, Dourdan, France; Development in Food Science 10; Amsterdam, The Netherlands, Elsevier, -277p.

Grimaldi J. 1978. The possibilities of improving techniques of pod breaking and fermentation in the traditional process of the preparation of cocoa. Café Cacao The, 22: 303-316

Guéhi ST, Dabone S, Ban-Koffi L, Kra DK, Zahouli GI. 2010. Effect of turning beans and fermentation method on the acidity and physical quality of raw cocoa beans. Adv. J. Food Sci. Technol, 2: 163-171.

Ho VT, Zhao J, Fleet G. 2014. Yeasts are essential for cocoa fermentation. Int. J. Food. Microbiol, 174: 72- 87. DOI: 10.1016/j.ijfoodmicro.2013.12.014;

Koffi O, Samagaci L, Goualie B, Niamke S. 2017. Diversity of Yeasts Involved in Cocoa Fermentation of Six Major CocoaProducing Regions in Ivory Coast. ESJ, 13 (30): 21 p. DOI: 1 0.1 9044/esj.201 7.v1 3n30p496;

Kouame L, Goualie BG, Adom, JN, Koua G, Ouattara HG, Doue G, Niamke LS. 2015a. Diversity of microbial strains involved in cocoa fermentation from Sud- Comoé (Ivory Coast) based on biochemical properties. ESJ, 11(18): 69-85. Available from: https://eujournal.org/index.php/esj/article/ download/5822/5637

Kouame LM, Doue GG, Adom NJ, Ouattara HG, Niamke SL. 2015b. Biochemical characterization of microbial populations involved in Loh-Djiboua cocoa's fermentationin Cote d'Ivoire. Food and Environment Safety, 14: 196-205. Available from: http://www.fia.usv.ro/fiajournal/index.php/ FENS/article/view/33
Krähmer A, Engel A, Kadow D, Ali N, Umaharan P, Kroh LW, Schulez H. 2015. Determination of biochemical quality parameters in cocoa using near infrared spectroscopy. Food Chem, 181:152-159. Available from: https://www.ncbi.nlm. gov/pubmed/25794734.

Lefeber T, Papalexandratou Z, Gobert W, Camu N, De Vuyst L. 2012. On-farm implementation of a starter culture for improved cocoa bean fermentation and its influence on the flavour of chocolates produced thereof. Food Microbiol, 30: 379-392. DOI: 10.1016/j.fm.2011.12.021;

Lima LJR, Almeida MH, Nout MJR, Zwietering MH. 2011. Theobromacacao L. "the food of the gods": quality determinants of commercial cocoa beans, with particular reference to the impact of the fermentation. Crit. Rev. Food Sci. Nutr., 52:731-761. Available from: https://www.ncbi. nlm.nih.gov/pubmed/21838556.

Minjares-Cassanco A, Trejor-Aguillas BA, Aguilar G. 1997. Physiological comparison between pectinase producing mutants of Aspergillus nigeradopted either to solid state fermentation or submerged fermentation. Enzyme Microb. Technol, 21:26-27.

Nielsen DS, Teniola OD, Ban-Koffi L, Owusu M, Anderson TS, Holzapfel WH. 2007. The microbiology of Ghanaian cocoa fermentations analysed using culture- dependent and culture-independent methods. Int. J. Food. Microbiol, 114:168-186. DOI: 10.1016/j.ijfoodmicro.2006.09.010;

Ouattara HD, Ouattara GH, Goualie BG, Kouame LM, Niamke SL. 2014. Biochemical and functional properties of lactic acid bacteria isolated from Ivorian cocoa fermenting beans. J. Appl. Biosci., 77: 6489-6499. DOI: 10.4314/jab.v77i1.9;

Ouattara HG, Ban-Koffi L, Karou GT, Sangare A, Niamke LS, Diopoh JK. 2008. Implication of Bacillus sp. in the production of pectinolytic enzymes during cocoa fermentation. World J Microb Biot, 24:1753-1760. DOI 10.1007/s11274-008-9683-9;

Ouattara HG, Reverchon S, Niamke SL, Nasser W. 2011. Molecular identification and pectate lyase production by Bacillus strains involved in cocoa fermentation. Food Microbiol, 28:1-8. DOI: 10.1016/j.fm.2011.01.010

Papalexandratou Z, De Vuyst L. 2011. Assessment of the yeast species composition of cocoa bean fermentations in different cocoa-producing regions using denaturing gradient gel electrophoresis. FEMS Yeast Res, 11: 564-574. DOI: 10.1016/j.fm.2011.01.010

Roelofsen PA. 1958. Fermentation, drying, and storage of cacao beans. Adv Food Res, 8: 225-296.

Rooijacker J, Kamphui HJ, Zwietering MH, Nout MJR. 2012. Microbiota dynamics and diversity at different stages of cocoa bean industrial processing to cocoa powder. Appl. Environ. Microbiol, 78: 2904-2913.

Saltini R, Akkerman R, Frosch S. 2013. Optimizing chocolate production through traceability. A review of the influence of farming practices on cocoa bean quality. Food Control, 29(1): 167-187. DOI: 10.1016/j.foodcont.2012.05.054;

Samagaci L, Ouattara HG, Goualié BG, Niamke SL. 2014. Growth capacity of yeasts potential starter strains under cocoa fermentation stress conditions in Ivory Coast. Emir $\mathbf{J}$ Food Agr, 26: 861 -870. DOI: 10.9755/ejfa.v26i10.18114;

Schwan RF, Wheals AE. 2004. The microbiology of cocoa fermentation and its role in chocolate quality. Crit. Rev. Food Sci. Nutr., 44(4): 205-221. DOI: 10.1080/10408690490464104;

Schwan RF, Cooper RM, Wheals AE. 1997. Endopolygalacturonase secretion by Kluyveromyces marxianus and other cocoa pulp-degrading yeasts. Enzyme Microb. Technol, 21: 234-244. DOI: 10.1016/S01410229(96)00261-X 
Sharma HC, Ortiz R. 2002. Host plant resistance to insects: an eco-friendly approach for pest management and environment conservation. J Environ Biol, 23: 111 -135. Available https://www.ncbi.nlm.nih.gov/pubmed/12602847.

Soares MMCN, Da Silva R, Gomes E. 1999. Screening of bacterial strains for pectinolytic activity: characterization of the polygalacturonase produced by Bacillus sp. Rev Microbiol, 30: 299-303. DOI: 10.1590/S000137141999000400002;
Thamthiankul S, Suan-Ngay S, Tantimavanich S, Panbangred W. 2001. Chitinase from Bacillus thuringiensis subsp. pakistani. Applied Microbiology and Biotechnology. Appl. Microbiol. Biotechnol, 56: 395-401. DOI: 10.1007/s002530100630;

Thompson SS, Miller KB, Lopez AS. 2001. Cocoa and coffee. Food Microbiol Fundamentals and Frontiers, 35: 721-733. DOI: 10.1128/9781555815912.ch39;

Thompson SS, Miller KB, Lopez AS. 2007. Cocoa and coffee. Food Microbiology. In: Doyle, M. P. and. Beuchat, L. R. (eds), Fundamentals and Frontiers. 3rd Edition, ASM Press, Washington, D. C, 837-850. 